\title{
THE EFFECT OF GENOTYPE ON DRESSING PERCENTAGE AND TISSUE CONTENT OF BEEF CARCASSES**
}

\author{
D. Ostojić-Andrić ${ }^{1 *}$, V. Bogdanović ${ }^{2}$, S. Aleksić ${ }^{1}$, M.M. Petrović ${ }^{1}$, \\ B. Miščević ${ }^{3}$, V. Pantelić ${ }^{1}$, S. Josipović ${ }^{1}$ \\ ${ }^{1}$ Institute for Animal Husbandry, Belgrade-Zemun, Serbia \\ ${ }^{2}$ Faculty of Agriculture, Zemun, Serbia \\ ${ }^{3}$ Faculty of Biofarming, Sombor, Serbia \\ *Corresponding author, e-mail: dusicaostojic@yahoo.com \\ ** Original scientific paper. Research financed by the Ministry of Science of Republic of \\ Serbia, Project TR 6887 B.
}

\begin{abstract}
Differences in dressing percentage and content of different tissues in carcasses of Domestic Spotted breed and crosses F1 generation with Charolais and Limousine breed were investigated. Total of 30 carcass sides were dissected, 10 in each genetic group. Genotype exhibited very significant effect $(p<0,01)$ on dressing percentage and content of tissues, except for connective tissue. The highest dressing percentage was determined in crosses with Charolais $(59,92 \%)$ followed by crosses with Limousine $(59,85 \%)$, with statistically significant difference $(p<0,01)$ to dressing percentage established for heads of domestic Simmental breed $(55,71 \%)$. Crosses with Charolais and Limousine realized considerably higher content of muscle tissue $(81,5 \%$ and $80,7 \%)$ compared to heads of domestic Simmental breed (77,86\%). Content of bone tissue of $16,45 \%$ in carcasses of domestic Simmental breed was considerably higher $(p<0,01)$ compared to both groups of crosses, whereas the content of fat and connective tissue was considerably higher $(p<0,05)$ only in relation to crosses with Limousine.
\end{abstract}

Key words: genotype, crossing, beef carcasses, dressing percentage, content of tissues.

\section{Introduction}

Muscle, bone and connective tissue are main components of meat as food. Individually, these tissues contribute not only in morphological- 
physiological sense, but traits of sensory, nutritive and edible quality of meat depend on the presence, composition and disposition of these tissues.

Muscle tissue is rich in biologically valuable proteins and protective substances, therefore it represents the most important and most valued meat component in the broad sense of the word. The efforts of selection experts in cattle production to favour genotypes which are characterized by higher share of muscle tissue in carcasses are therefore justified. Considering that dressing percentage as quantitative indicator of meat quality greatly depends on presence of fat tissue, reliable data on content of muscle tissue in carcass can be obtained exclusively by is separation by dissection of carcass sides.

In our country, according to data of the Bureau of Statistics of Republic of Serbia, in year 2006182.000 cattle were fattened and 83.000t of beef produced, i.e. $170 \mathrm{~kg}$ of meat per head with average dressing percentage of $54-55 \%$. Statistical data indicate the need for improvement of the carcass quality traits of existing fattening material, i.e. heads of cattle of Domestic Spotted breed from which most of the meat on the market originates.

One of the ways for fast and efficient improvement of stated traits is by method of industrial crossing of Domestic Simmental breed with French fattening breeds, Charolais and Limousine, which are characterized with excellent carcass quality. In this way, in offspring of F1 generation the effect of heterosis is utilized by non-additive gene effect and effect of complementarity of hereditary bases by additive gene effect. Effects of this method on investigated traits were investigated by several groups of authors who obtained different research results.

In research by Medić et al. (1991) crosses with Limousine realized considerable increase of dressing percentage and of content of muscle tissue and at the same time decrease of share of bones and fat, compared to control group, or Domestic Simmental cattle.

According to results obtained by Nosal et al. (1993), yield of meat was by $2,38 \%$ higher in crosses of Limousine with Slovak Spotted cattle in relation to initial breed.

Miščević et al. (1997) state positive deviations of the heads of genotype $\mathrm{DS} \times \mathrm{Ch}$ and DS $\times$ Li from general average for meat yield in carcass sides contrary to heads of Domestic Simmental breed, where negative deviation of meat yields in carcass sides was $-10,41 \mathrm{~kg}$.

In this paper the effect of industrial crossing of Domestic Simmental breed with French fattening breeds, Charolais and Limousine, on dressing percentage and content of tissues in carcasses was investigated. 


\section{Material and methods}

Establishing of differences in content of muscle, bone, fat and connective tissue was carried out by total dissection of 30 beef carcass sides $(3 \times 10)$ of three genotype groups:

1) genotype G1: cattle of Domestic Simmental breed as control group (DS)

2) genotype G2: cattle crosses of $F_{1}$ generation of Domestic Simmental breed and Limousine $(\mathrm{DS} \times \mathrm{Li})$

3) genotype G3: cattle crosses of $F_{1}$ generation of Domestic Simmental breed and Charolais $(\mathrm{DS} \times \mathrm{Ch})$

Trial cattle were reared on experimental farm of the Institute for Animal Husbandry, Belgrade-Zemun, in free housing system, fed concentrated feeds, hay and maize silage. After evaluation of the degree of fattening and realized desired body mass (approx. $600 \mathrm{~kg}$ ), cattle were slaughtered, carcasses were processed and weighed in order to determine the value of slaughter yield.

Processing of results was done using statistical programme StatSoft.Inc (1995), Statistica for Windows, where, beside basic parameters of descriptive statistics (mean value, standard deviation and variation coefficient), by variance analysis also the effect of genotype on investigated traits was determined, and statistical significance of differences between certain genotypes determined by t-test.

\section{Results and discussion}

According to table 1, the highest dressing percentage of carcass was established in crosses with Charolais $(59,92 \%)$ than Limousine $(59,85 \%)$, with statistically significant difference $(p<0,01)$ to dressing percentage of heads of Domestic Simmental breed (55,71\%). The highest individual value of dressing percentage of $66,21 \%$, was calculated in cross with Limousine.

The greatest mass of cold carcass was also realized by crosses with Charolais $(372,6 \mathrm{~kg})$ and Limousine $(360,0 \mathrm{~kg})$ and the smallest by heads of Domestic Spotted breed $(324,1 \mathrm{~kg})$, the effect of genotype was $p<0,01$.

Results of the value of dressing percentage determined in this trial weren't in accordance with results obtained by Miščević et al. (1997) and Medić et al. (1991) who determined the highest dressing percentages of 
$60,1 \%$ and $63,7 \%$ in heads of genotype DS $\times$ Li. However, in paper by Miščević et al. (1997) in accordance with dressing percentage, mass of carcass with fat was the greatest in genotype DS $\times$ Li $(353,8 \mathrm{~kg})$, Medic et al. (1991) determined the greatest average mass of warm carcass sides in heads of genotype DS $\times$ Ch $(333,5 \mathrm{~kg})$ which is in accordance with results of this research where the greatest boy mass of carcasses of $372,6 \mathrm{~kg}$ was realized by Charolais crosses.

In trial by Dhuyvetter et al. (1985) higher values of dressing percentage in crosses were determined in relation to those determined in our research (table 1). So, crosses with Charolais realized by $0,7 \%$ lower dressing percentage than crosses with Limousine $(64,6 \%)$, but because of greater masses prior to slaughtering, their carcasses were heavier by approx. $7 \mathrm{~kg}$ $(332,1 \mathrm{~kg})$.

Table 1. The effect of genotype on dressing percentage.

\begin{tabular}{|c|c|c|c|c|c|c|c|c|c|c|c|c|c|}
\hline \multirow{3}{*}{$\begin{array}{c}\text { GENOTYPE } \\
\text { TRAITS }\end{array}$} & \multirow{2}{*}{\multicolumn{3}{|c|}{$\begin{array}{c}\text { DOM. SIM. } \\
\text { (G1) } \\
\mathrm{N}=10\end{array}$}} & \multirow{2}{*}{\multicolumn{3}{|c|}{$\begin{array}{c}\text { DS } \times \\
\text { LIMOUSINE } \\
(\mathrm{G} 2) \\
\mathrm{N}=10\end{array}$}} & \multirow{2}{*}{\multicolumn{3}{|c|}{$\begin{array}{c}\text { DS } \times \\
\text { SHAROLAIS } \\
(\mathrm{G} 3) \\
\mathrm{N}=10\end{array}$}} & \multirow{3}{*}{$\mathrm{F}$} & \multirow{2}{*}{\multicolumn{3}{|c|}{$\begin{array}{c}t \\
\text { TEST }\end{array}$}} \\
\hline & & & & & & & & & & & & & \\
\hline & $\overline{\mathbf{x}}$ & $\mathbf{S}$ & CV & $\bar{x}$ & $\mathbf{S}$ & CV & $\overline{\mathbf{x}}$ & $\mathbf{S}$ & CV & & $\frac{\text { G1 }}{\text { G2 }}$ & $\frac{\text { G1 }}{\text { G3 }}$ & $\frac{\text { G2 }}{\text { G3 }}$ \\
\hline $\begin{array}{l}B M \\
\text { At the end of } \\
\text { fattening, } \\
\mathrm{kg}\end{array}$ & 579 & 35,6 & 6,15 & 590 & 47,2 & 8,0 & 621 & 47,9 & 7,71 & $* *$ & NS & $* *$ & $*$ \\
\hline $\begin{array}{l}\text { Mass of cold } \\
\text { carcass, } \mathrm{kg}\end{array}$ & 324 & 32,6 & 10,1 & 360 & 33,1 & 9,2 & 373 & 35,5 & 9,54 & $* *$ & $* *$ & $* *$ & NS \\
\hline $\begin{array}{l}\text { Dressing } \\
\text { percentage } \\
\text { with fat, \% }\end{array}$ & 55,7 & 2,63 & 4,7 & 59,8 & 3,59 & 6,00 & 59,9 & 2,92 & 4,87 & $* *$ & $* *$ & $* *$ & NS \\
\hline
\end{tabular}

Results in table 2 show that the highest share of muscle tissue of $81,5 \%$, was established by total dissection in crosses with Limousine, and somewhat lower value in crosses with Charolais $80,7 \%$. Differences in content of meat to heads of Domestic Simmental breed $(77,86 \%)$ were statistically highly 
significant.

Heads of Domestic Simmental breed realized considerably higher $(p<0,01)$ share of bones of $16,45 \%$ in relation to crosses with Limousine $(14,42 \%)$ and Charolais $(14,69 \%)$.

The highest content of fat tissue was established in carcass sides of Domestic Simmental heads $(5,26 \%)$, than crosses with Charolais $(4,12 \%)$ and Limousine $(3,50 \%)$. Differences in content of fat tissue were statistically significant $(\mathrm{p}<0,05)$ only between Domestic Simmental cattle and crosses with Limousine.

Domestic Simmental breed is characterized by the highest content of connective tissue in carcass sides $(0,44 \%)$, differences were statistically significant at the level of $\mathrm{p}<0,05$ in relation to crosses with Limousine $(0,35 \%)$.

Table 2. The effect of genotype on tissue content of beef carcass, $\%$.

\begin{tabular}{|c|c|c|c|c|c|c|c|c|c|c|c|c|c|}
\hline \multirow{2}{*}{$\begin{array}{c}\text { GENOTYPE } \\
\text { TRAITS }\end{array}$} & \multicolumn{3}{|c|}{$\begin{array}{c}\text { DOM. SIM. } \\
\text { (G1) } \\
\mathrm{N}=10\end{array}$} & \multicolumn{3}{|c|}{$\begin{array}{c}\text { DS X } \\
\text { LIMOUSINE } \\
(\mathrm{G} 2) \\
\mathrm{N}=10\end{array}$} & \multicolumn{3}{|c|}{$\begin{array}{c}\text { DS X } \\
\text { CHAROLAIS } \\
\text { (G3) } \\
\mathrm{N}=10\end{array}$} & \multirow[t]{2}{*}{$\mathrm{F}$} & \multicolumn{3}{|c|}{$\stackrel{t}{\mathrm{t}}$} \\
\hline & $\bar{x}$ & $\mathbf{S}$ & $\mathrm{CV}$ & $\bar{x}$ & $\mathbf{S}$ & $\mathrm{CV}$ & $\bar{x}$ & $\mathbf{S}$ & $\mathrm{CV}$ & & $\frac{\mathrm{G} 1}{\mathrm{G} 2}$ & $\frac{\text { G1 }}{\text { G3 }}$ & $\frac{\mathrm{G} 2}{\mathrm{G} 3}$ \\
\hline $\begin{array}{l}\text { Muscle } \\
\text { tissue }\end{array}$ & 77,86 & 2,23 & 2,87 & 81,50 & 2,26 & 2,77 & 80,70 & 1,21 & 1,50 & $* *$ & $* *$ & $* *$ & NS \\
\hline Bone tissue & 16,45 & 1,20 & 7,27 & 14,42 & 1,57 & 10,8 & 14,69 & 0,72 & 4,89 & $* *$ & $* *$ & $* *$ & NS \\
\hline Fat tissue & 5,26 & 1,37 & 26,1 & 3,74 & 1,18 & 31,6 & 4,23 & 1,14 & 26,9 & $*$ & $*$ & NS & NS \\
\hline $\begin{array}{l}\text { Connective } \\
\text { tissue }\end{array}$ & 0,44 & 0,10 & 23,6 & 0,35 & 0,07 & 21,5 & 0,37 & 0,08 & 21,3 & NS & $*$ & NS & NS \\
\hline
\end{tabular}

These results are in accordance with research results of Nosal et al. (1993) who established meat yield in carcass sides higher by $2,38 \%$ than in crosses of Limousine with Slovak Spotted cattle in relation to initial breed. 
In trial by Medić et al. (1991) increase of content of muscle tissue $(+3,08 \%)$ and decrease of share of bone tissue $(-2,28 \%)$ in Limousine crosses compared to heads of Domestic Simmental breed was determined, which is similar to results obtained in this research.

\title{
Conclusion
}

Based on research results it can be concluded that there is significant effect of genotype on value of dressing percentage and content of tissues in carcass sides.

It was confirmed that dressing percentage doesn't represent reliable indicator of the content of muscle tissue in carcasses, considering that the highest values of dressing percentage were established in crosses with Charolais, and by dissection the highest content of muscle tissue was determined in crosses with Limousine.

According to results of total dissection, it is clear that carcasses of Domestic Simmental breed are less desirable on the market since they have higher share of bone and connective tissue, and the lowest share of muscle tissue. On the other hand, differences between crosses, although without statistical significances, favour crosses with Limousine since in their carcasses the highest share of meat and the lowest share of fat, bone and connective tissue were established.

\section{UTICAJ GENOTIPA NA RANDMAN I SADRŽAJ TKIVA U JUNEĆIM TRUPOVIMA}

\author{
D. Ostojić-Andrić, V. Bogdanović, S. Aleksić, M.M. Petrović, \\ B. Miščević, V. Pantelić, S. Josipović
}

\section{Rezime}

Proučavane su razlike u randmanu i sadržaju tkiva u trupovima između domaće simentalske rase i njenih meleza F1 generacije sa šarole i limuzin rasom. Ukupno je disecirano 30 polutki, po $10 \mathrm{u}$ svakoj genotipskoj grupi. Genotip je ispoljio vrlo značajan uticaj $(p<0,01)$ na randman i sadržaj tkiva, izuzev udela vezivnog tkiva. Najveći randman utvrđen je kod meleza sa šaroleom $(59,92 \%)$ pa limuzinom $(59,85 \%)$, uz statistički značajnu razliku 
$(\mathrm{p}<0,01)$ prema randmanu grla domaće simentalske rase $(55,71 \%)$. Melezi limuzina i šarolea ostvarili su značajno veći sadržaj mišićnog tkiva $(81,5 \%$ i $80,7 \%)$ u odnosu na grla domaće simentalske rase (77,86\%). Sadržaj koštanog tkiva od $16,45 \%$ u trupovima domaće simentalske rase bio je značajno veći $(\mathrm{p}<0,01)$ u odnosu na obe grupe meleza, dok je sadržaj masnog i vezivnog tkiva bio značajno veći $(p<0,05)$ samo u odnosu na meleze limuzina.

\section{References}

ALEKSIĆ S., MIŠČEVIĆ B., PETROVIĆ M.M., ILIĆ Z., D. TOMAŠEVIĆ (1999): The Influence of Genotype on The Quality of Young Bull Carcass. Biotechnology in Animal Husbandry, 15, (3-4), p. 53-59.

DHUYVETTER J.M., FRAHM R.R., MARSHALL D.M. (1985): Comparison of Charolais and Limousine as terminal cross sire breeds. Journal of Animal Science, 60, p. 935.

LAZAREVIĆ R. (1988): Francuske tovne rase za poboljšanje mesa domaćeg šarenog govečeta. Ekonomika poljoprivrede-Beograd.

MEDIĆ D., VESELINOVIĆ S., D. PETKOVIĆ, BODULIĆ S. (1991): Ispitivanje tovnih i klaničnih osobina meleza dobijenih ukrštanjem krava kombinovanog i mlečnog tipa sa bikovima tovnih rasa. Biotehnologija u stočarstvu, 7, 1-2, p.15-24.

MIŠČEVIĆ B., LAZAREVIĆ R., ALEKSIĆ S., PETROVIĆ M., JOSIPOVIĆ S. (1997): Fixed Influence of Genotype on production Traits of Young Cattle. I ${ }^{\text {st }}$ Yugoslav International Congress on Animal Husbandry Biotechnology in Animal Husbandry, 13, 3-4, p.65-72.

MIŠČEVIĆ B., ALEKSIĆ S., PETROVIĆ M.M, LAZAREVIĆ R., JOSIPOVIĆ S., SMILJAKOVIĆ T., MARINKOV G., TOMAŠEVIĆ D., OSTOJIĆ D. (2003): Uticaj genotipa na važnije osobine kvaliteta trupa junadi. VII Međunarodni simpozijum, Savremeni trendovi u stočarstvu, Biotehnologija u stočarstvu, vol 19, 5-6, p. 35-40.

NOSAL V., CUBON J., PALANSKA O., DANO J. (1993): Carcass value and meat quality of bulls of improved slovak spotted cattle and cross-breed with limousine breed. Polnohospodarstvo, 39, 1, p.44.

STATISTICA FOR WINDOWS. Computer programm manual. StatSoft.Inc. (1995), Tulsa, OK.

STATISTIČKI GODIŠNJAK SRBIJE (2006). Zavod za statistiku Republike Srbije. 